\title{
Morphometric Study of Nutrient Foramina in Dry Human Clavicles in Central India
}

\author{
Harsha Atul Keche ${ }^{1}$, Preeti Prabhakar Thute 2 , Darshna Gulabrao Fulmali ${ }^{3}$, Atul Shankarrao Keche ${ }^{4}$ \\ 1,2,3 Department of Anatomy, Jawaharlal Nehru Medical College (Deemed to Be University), \\ Sawangi (Meghe), Wardha, Maharashtra, India. ${ }^{4}$ Department of Forensic Medicine \& \\ Toxicology, All India Institute of Medical Sciences, Bhopal, Madhya Pradesh, India.
}

\section{ABSTRACT}

\section{BACKGROUND}

The clavicle or collar bone is a modified long bone. It is the first bone to ossify in the membrane. The inferior surface of shaft of clavicle presents a subclavian groove. A nutrient foramen lies at the lateral end of the groove. The nutrient artery is derived from the supraclavicular or clavicular branch of thoracoacromial artery. A bone is supplied by a nutrient artery which passes through the small tunnel called as nutrient foramina. In orthopaedic procedures to preserve the circulation, the topographical knowledge of the nutrient foramen is important. The study was undertaken to analyse nutrient foramina in adult human clavicles in relation to their number, position, direction, and distribution over bone length.

\section{METHODS}

Our study consisted of 67 adult dry human clavicles (31 right sides and 36 left sides). The number, topography and direction of the foramina were studied. The distance of foramina from the sternal end \& total length of the clavicles were measured in millimetres by using digital Vernier calipers. The foramen index was calculated by applying the Hughes formula: $\mathrm{FI}=\frac{(\mathrm{DNF}}{\mathrm{TL})} \times 100$.

\section{RESULTS}

Nutrient foramina were present in all the clavicles. Most of the clavicles have single nutrient foramen. We observed $62(68.13 \%)$ foramina on the posterior surface mostly in the middle 1 / 3 rd region. All the nutrient foramina were directed towards acromial end and the foramina index (FI) was 50.2.

\section{CONCLUSIONS}

The topographical knowledge of the nutrient foramen is important in orthopaedic procedures like nail plating, $\mathrm{K}$ wire fixation, reduction, internal fixation devices for the treatment of fracture, coracoclavicular ligament repair and in free vascularized bone graft to preserve the circulation.

\section{KEY WORDS}

Clavicle, Nutrient Foramina, Nutrient Artery, Foramina Index (FI)
Corresponding Author: Dr. Preeti Prabhakar Thute, C/o Dr. B. C. Bakane,

Tathastu, in front of Ajit Sunder Palace Apartment, Near Shanti stup, Laxminagar, Wardha - 442001, Maharashtra, India. E-mail: b_bakane@rediffmail.com

DOI: $10.14260 /$ jemds/2021/429

How to Cite This Article?

Keche HA, Thute PP, Fulmali DG, et al. Morphometric study of nutrient foramina in dry human clavicles in Central India. J Evolution Med Dent Sci 2021;10(28): 2099-2103, DOI:

$10.14260 /$ jemds/2021/429

Submission 10-10-2020,

Peer Review 25-01-2021,

Acceptance 02-02-2021,

Published 12-07-2021.

Copyright (C) 2021 Harsha Atul Keche et al. This is an open access article distributed under Creative Commons Attribution License [Attribution 4.0 International (CC BY 4.0)] 


\section{BACKGROUND}

Human beings have adopted upright posture and bipedal locomotion $^{1}$ and the arm swings clearly away from the trunk so that the clavicle acts as a strut. ${ }^{2}$ The clavicle or collar bone is a modified long bone, subcutaneous throughout and lies horizontally in the body at the root of the neck.[1] The word clavicle is derived from Latin word meaning 'key' and resembles the Latin letter ' $\mathrm{f}$. ${ }^{3}$ It has unique features like it is the first bone to ossify in membrane and completes its ossification by about 25 years.

The clavicle has two ends medial and lateral and a shaft which is a cylindrical part. The sternoclavicular joint is formed when the medial (sternal) end articulates with the clavicular notch of the manubrium sterni. The first costal cartilage articulates with the inferiorly extended articular surface of the sternal end. The acromioclavicular joint is formed by the articulation of the lateral (acromial) end with the acromion process of the scapula. ${ }^{1}$

The shaft is divisible into medial two thirds and the lateral one third. The lateral one third of the shaft has two surfaces superior and inferior, two borders anterior and posterior. Its superior surface is subcutaneous. The conoid tubercle and the trapezoid ridge is present on the inferior surface. The medial two third of the shaft is rounded and has four surfaces. Its anterior surface is convex forwards while posterior surface is smooth. A rough oval impression is present on the medial end of the inferior surface. A longitudinal subclavian groove is present at the lateral half of this surface. At the lateral end of the groove, nutrient foramen lies which runs in a lateral direction. ${ }^{1}$ The nutrient artery is derived from the supraclavicular or clavicular branch of thoracoacromial artery. ${ }^{4}$ When the nutrient foramina are absent in the clavicle, the blood supply is from the periosteal network. ${ }^{5}$

A bone is supplied by a nutrient artery which passes through the small tunnel called as a nutrient foramina or neurovascular foramina. During active growth period of the long bone the principle source of blood is the nutrient artery. ${ }^{5}$ Berard in 1835 was the first to correlate the direction of the nutrient canals with the mode of bone's ossification and growth. ${ }^{6}$ The variations in direction of the nutrient foramina in long bones were first explained by Humphrey in 1861. He suggested that position of the nutrient artery and direction of its canals are determined by the interaction of interstitial growth of periosteum and oppositional growth of bone. ${ }^{7}$

The topographical knowledge of the nutrient foramen is important in orthopaedic procedures like nail plating, $\mathrm{K}$ wire fixation, reduction, internal fixation devices for the treatment of fracture, coracoclavicular ligament repair and in free vascularized bone graft to preserve the circulation ${ }^{2,8}$ as the periosteal and endosteal blood supply with good anastomosis is essential for ideal bone graft. ${ }^{9}$

The study was undertaken to analyse nutrient foramina in adult human clavicles in relation to their number, position, direction, and distribution over bone length.

\section{METHODS}

A cross sectional study was carried out in the Anatomy department of Jawaharlal Nehru Medical college, Sawangi
(M), Wardha, from, October 2019 to September 2020 after obtaining IEC (Institutional Ethical Committee) clearance. As per the literature available, we included 67 adult dry human clavicles (31 right sides and 36 left sides) of unknown age and sex, without any pathological changes, deformity, or fracture in the present study. Number, position, and direction of the nutrient foramina were observed by using a magnifying lens. We have identified the nutrient foramina by the presence of a well-marked groove leading to the foramen.

The number, topography, and direction of the neurovascular foramina in relation to borders or surfaces of the shaft were analysed. The nutrient foramina within $1 \mathrm{~mm}$ from any border were considered lying on that border. To confirm patency of the nutrient foramina a needle was passed through each foramen. The total length of the clavicles and the distance of foramina from the sternal end were measured in millimetres by using digital vernier caliper, ignoring curves of clavicles.

Each clavicle was divided into three equal regions i.e.; medial 1 / 3rd, middle 1 / 3rd and lateral 1 / 3rd and the location of the foramen was noted. The foramina were topographically classified into 1 / 3 regions (medial $1 / 3$, middle 1 / 3 and lateral 1 / 3).

$$
\text { Hughes formula : FI }=\frac{(\mathrm{DNF}}{\mathrm{TL})} \times 100
$$

was applied to calculate the foramina index. DNF $=$ The distance from the proximal end (sternal end) of the clavicle to the nutrient foramen. $\mathrm{TL}=$ total length of clavicle. ${ }^{10}$

\section{Statistical Analysis}

Statistical analysis was done by chi square test. Software SPSS 24.0 version and Graph Pad Prism 7.0 V was used.

\section{RESULTS}

\begin{tabular}{|ccccc|}
\hline $\begin{array}{c}\text { No. of Nutrient } \\
\text { Foramina }\end{array}$ & Right (N = 31) & Left $(\mathbf{N}=\mathbf{3 6})$ & Total $(\mathbf{N}=\mathbf{6 7}) \mathbf{X 2}$ - Value \\
1 & $21(67.74 \%)$ & $23(63.89 \%)$ & $44(65.67 \%)$ & \\
2 & $10(32.26 \%)$ & $12(33.33 \%)$ & $22(32.84 \%)$ & 0.90 \\
3 & 00 & $01(2.78 \%)$ & $01(1.49 \%)$ & $\mathrm{P}=0.63, \mathrm{NS}$ \\
\hline \multicolumn{5}{c}{ Table 1. No. of Nutrient Foramina } \\
\hline
\end{tabular}

The nutrient foramina were observed in all 67 (100\%) clavicles. In 44 (65.67\%) single foramen and in 22 (32.84\%) double foramina were present. Most of the right clavicles contained single foramen $21(67.74 \%)$. Three foramina were present in only one clavicle of left side. The number of nutrient foramina on both the sides was found statistically insignificant. (Table 1).

\begin{tabular}{|c|c|c|c|c|c|c|c|}
\hline \multirow{2}{*}{$\begin{array}{c}\text { Side of } \\
\text { the } \\
\text { Clavicle }\end{array}$} & \multicolumn{4}{|c|}{ Medial $2 / 3^{\text {rd }}$} & \multicolumn{2}{|c|}{ Lateral 1 / 3rd } & \multirow{2}{*}{$\begin{array}{c}\text { Total no. of } \\
\text { Nutrient } \\
\text { Foramina }\end{array}$} \\
\hline & $\begin{array}{l}\text { Ante } \\
\text { rior }\end{array}$ & Posterior & $\begin{array}{l}\text { Supe- } \\
\text { rior }\end{array}$ & Inferior & $\begin{array}{l}\text { Supe- } \\
\text { rior }\end{array}$ & $\begin{array}{l}\text { Infe- } \\
\text { rior }\end{array}$ & \\
\hline Right & - & $\begin{array}{c}30 \\
(32.97 \%)\end{array}$ & - & $\begin{array}{c}09 \\
(9.89 \%)\end{array}$ & $\begin{array}{c}1 \\
(1.10 \%)\end{array}$ & $\begin{array}{c}1 \\
(1.10 \%)\end{array}$ & $\begin{array}{c}41 \\
(45.06 \%)\end{array}$ \\
\hline Left & - & $\begin{array}{c}32 \\
(35.16 \%)\end{array}$ & - & $\begin{array}{c}18 \\
(19.78 \%)\end{array}$ & 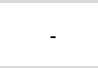 & - & $\begin{array}{c}50 \\
(54.94 \%)\end{array}$ \\
\hline Total & - & $\begin{array}{c}62 \\
(68.13 \%)\end{array}$ & & $\begin{array}{c}27 \\
(29.67 \%)\end{array}$ & $\begin{array}{c}1 \\
(1.10 \%)\end{array}$ & $\begin{array}{c}1 \\
(1.10 \%)\end{array}$ & $\begin{array}{c}91 \\
(100 \%)\end{array}$ \\
\hline X2-value & \multicolumn{7}{|c|}{$4.21, \mathrm{P}$-value $=0.23, \mathrm{NS}, \mathrm{P}>0.05$} \\
\hline \multicolumn{8}{|c|}{ Table 2. Location of Nutrient Foramina on the Surfaces } \\
\hline
\end{tabular}


Total number of nutrient foramina observed was 91 . Out of which, $10(10.98 \%)$ were present on the inferior surface of the right clavicle. Of these 09 (9.89\%) were on medial 2 / 3rd and $1(1.10 \%)$ on lateral 1 / 3rd of right side clavicle. Right sided clavicle had 30 (32.97\%) and 1 (1.10\%) nutrient foramina on posterior and superior surfaces respectively. 32 $(35.16 \%)$ and $18(19.78 \%)$ nutrient foramina were present on posterior and inferior surfaces of left side respectively. The location of nutrient foramina on the surfaces of both the sides was found statistically insignificant. (Table 2)

\begin{tabular}{|cccc|}
\hline Parts of Clavicle & $\begin{array}{c}\text { Number of Nutrient } \\
\text { Foramina }\end{array}$ & $\begin{array}{c}\text { Number of } \\
\text { Clavicles }\end{array}$ & X2 - Value \\
Medial 1 / 3rd & $20(21.98 \%)$ & $17(25.37 \%)$ & \\
Middle 1 / 3rd & $66(72.52 \%)$ & $45(67.17 \%)$ & 0.58 \\
Lateral 1 / 3rd & $05(5.50 \%)$ & $05(7.46 \%)$ & $\mathrm{P}=0.74, \mathrm{NS}$ \\
\hline Total & $91(100 \%)$ & $67(100 \%)$ & \\
\hline \multicolumn{4}{|r}{ Table 3. Length Wise Distribution of Nutrient Foramina } \\
\hline
\end{tabular}

$20(21.98 \%)$ foramina were present on the medial $1 / 3^{\text {rd }}$ region, $66(72.52 \%)$ on the middle $1 / 3^{\text {rd }}$ region and 05 $(5.50 \%)$ on lateral $1 / 3^{\text {rd }}$ region respectively. Maximum foramina were present in middle $1 / 3^{\text {rd }}$ of the clavicle i.e. 66 $(72.52 \%)$. The length wise distribution of nutrient foramina on the surfaces of both sides was found statistically insignificant. (Table 3)

All the nutrient foramina were directed towards acromial end, i.e. away from the growing end. Mean length of the clavicle of right and left side was found $133.1 \pm 0.67 \mathrm{~mm}$ and $135.6 \pm 0.5 \mathrm{~mm}$ respectively. DNF of right and left clavicle was $63.2 \pm 1.21 \mathrm{~mm}$ and $62.8 \pm 0.62 \mathrm{~mm}$ respectively. Foramina index (FI) was $47.48 \mathrm{~mm}$ and $46.31 \mathrm{~mm}$ of right and left side clavicle respectively.

\section{DISCUSSION}

The external opening of the neurovascular canal is the nutrient foramen and it has a particular position in each bone. The role of nutrient foramina is the growth of the bone and to provide nutrition, the term "Nutrient" itself apprehends it. 11

In the present study nutrient foramina were present in 67 (100 \%) clavicles. Murlimanju BV et al. ${ }^{9}$ Rai R et al. ${ }^{12}$ Tanna N et al. ${ }^{13}$ and Sahu S et al. ${ }^{14}$ also observed presence of nutrient foramina in each clavicle while other authors found absence of nutrient foramina in clavicles. Some authors reported that clavicles are supplied by the periosteal arteries, when there is absence of nutrient foramina. Knudsen et al. ${ }^{15}$ reported that the periosteal artery becomes the sole source of blood supply in the bones in which the nutrient foramina is absent.

\begin{tabular}{|cccccc|}
\hline Researchers & $\mathbf{5}$ & \multicolumn{5}{c|}{ Number of Nutrient Foramina } \\
& $\mathbf{0}$ & $\mathbf{1}$ & $\mathbf{2}$ & $\mathbf{3}$ & More Than \\
Murlimanju BV et \\
$\begin{array}{c}\text { al. (2014) } \\
\text { Rai R et al. } \\
(2014)^{12}\end{array}$ & - & $38.5 \%$ & $44.2 \%$ & $13.4 \%$ & - \\
$\begin{array}{c}\text { TannaN et al. } \\
(2015)^{13}\end{array}$ & - & $42.5 \%$ & $52.5 \%$ & $5 \%$ & - \\
$\begin{array}{c}\text { Sowmiya G et al } \\
(2016)^{5}\end{array}$ & $7(6.4 \%)$ & $80(72.7 \%)$ & $18(16.4 \%)$ & $4(3.6 \%)$ & $1(0.9 \%)$ \\
$\begin{array}{c}\text { Sahu S (2017) } \\
\text { Joshi P et al. } \\
(2018)^{16}\end{array}$ & $-3(6 \%)$ & $34(68 \%)$ & $13(26 \%)$ & 0 & - \\
Rekha et al. & $4.7 \%$ & $36.5 \%$ & $28.3 \%$ & $4.7 \%$ & \\
\hline
\end{tabular}

\begin{tabular}{|ccccc|}
\hline $\begin{array}{c}(2019)^{8} \\
\text { Kumar D et al. } \\
(2019)^{2}\end{array}$ & $9.80 \%$ & $73.52 \%$ & $14.70 \%$ & $1.96 \%$ \\
$\begin{array}{c}\text { Present study } \\
(2020)\end{array}$ & - & $44(65.67 \%)$ & $22(32.84 \%)$ & $01(1.49 \%)$ \\
\hline Table 4. Comparison of Number of Nutrient Foramina \\
with Different Researchers
\end{tabular}

Joshi P et al. ${ }^{16}$ observed single foramen in 34 (68 \%) while we found 44 (65.67\%) clavicles having single foramen which is in concurrence with our study. In the present study double foramina were present in 22 (32.84\%) clavicles while Rai R et al. ${ }^{12}$ TannaN et al. ${ }^{13}$ and Sahu $\mathrm{S}^{14}$ in their study observed more than $50 \%$ clavicles had double foramina. Three foramina were present in only one clavicle of left side in the present study. Sowmiya G et al. ${ }^{5}$ observed $1(0.9 \%)$ clavicle having three foramina. Patake SM and Mysorekar VR (1977) ${ }^{5}$ opined that there is no significant relation between the number of foramina to the bone. They also described that the number of ossification centres may not have relation with the number of foramina, as the clavicle generally has a single foramen but has two primary centres while the femur usually has two foramina but has one primary centre of ossification.

\begin{tabular}{|c|c|c|c|c|}
\hline \multirow[t]{2}{*}{ Researchers } & \multicolumn{4}{|c|}{ Location of Nutrient Foramina } \\
\hline & Inferior & Posterior & Superior & Anterior \\
\hline Murlimanju BV et al. (2014) ${ }^{9}$ & $55.8 \%$ & $69.2 \%$ & $1.9 \%$ & - \\
\hline Rai R et al. (2014) ${ }^{12}$ & $23(35.4 \%)$ & $23(42.6 \%)$ & - & - \\
\hline Tanna N et al. $(2015)^{13}$ & $30(36.6 \%)$ & $52(63.4 \%)$ & - & - \\
\hline Sowmiya G et al. $(2016)^{5}$ & $34(30.9 \%)$ & $80(72.7 \%)$ & $6(5.4 \%)$ & \\
\hline Sahu S $(2017)^{14}$ & $31(36.9 \%)$ & $53(63.1 \%)$ & - & - \\
\hline $\begin{array}{l}\text { Joshi P et al. } \\
(2018)^{16}\end{array}$ & $8(16 \%)$ & $38(76 \%)$ & $1(2 \%)$ & - \\
\hline Rekha et al. $(2019)^{8}$ & $39(62.9 \%)$ & $21(33.8 \%)$ & - & $1(3.22 \%)$ \\
\hline Kumar D et al. (2019)² & $14.13 \%$ & $85.86 \%$ & - & - \\
\hline Present study (2020) & $28(30.77 \%)$ & $62(68.13 \%)$ & $1(1.10 \%)$ & - \\
\hline \multicolumn{5}{|c|}{$\begin{array}{l}\text { Table 5. Comparison of Position of Nutrient Foramina in } \\
\text { elation to the Surfaces According to Different Researchers }\end{array}$} \\
\hline
\end{tabular}

In the present study total number of nutrient foramina observed was 91 . We observed $62(68.13 \%)$ foramina on the posterior surface. In the study conducted by TannaN et al. ${ }^{13}$ Sowmiya G et al. ${ }^{5}$ Sahu S ${ }^{14}$ Joshi P et al. ${ }^{16}$ and Kumar D et al. ${ }^{2}$ their findings suggest that nutrient foramina are more common on the posterior surface. Rekha et al. ${ }^{8}$ observed 1 $(3.22 \%)$ foramen on the anterior surface. Murlimanju BV et al. ${ }^{9}$ Sowmiya G et al. ${ }^{5}$ Joshi P et al. ${ }^{16}$ found $1.9 \%, 6$ (5.4 \%), 1 (2\%) nutrient foramina on the superior surface respectively, while in our study $1(1.10 \%)$ neurovascular foramen was present on the superior surface. The nutrient foramina are occupied by the vessels that are involved in the initial invasion of the ossifying cartilage which is generally agreed. ${ }^{9}$ The position of nutrient foramina is affected by the factors like bone remodelling and the growth rates of two ends of the shaft. 12

In our study we observed $66(72.52 \%)$ nutrient foramina at the middle 1 / 3 rd region of the clavicle. Murlimanju BV et al. ${ }^{9}$ Rai R et al..$^{12}$ Tanna $N$ et al. ${ }^{13}$ Sowmiya G et al..$^{5}$ and Joshi $P$ et al. ${ }^{16}$ found maximum number of foramina on the middle 1 / $3^{\text {rd }}$ of the clavicle. While Rekha et al. ${ }^{8}$ in their study observed 4 (66.6\%) nutrient foramina on the lateral 1 / 3rd of the clavicles. The relation of the length of clavicle to the location of nutrient foramina is of great clinical importance as the clavicle is commonly fractured at the junction of its two curvatures which is the weakest point of the bone by falling on the outstretched hand. ${ }^{1}$ 


\begin{tabular}{|c|c|c|c|}
\hline \multirow{2}{*}{ Researchers } & \multicolumn{3}{|c|}{ Location of Nutrient Foramina } \\
\hline & Medial 1 / 3rd & $\begin{array}{c}\text { Middle } 1 \text { / } \\
\text { 3rd }\end{array}$ & $\begin{array}{c}\text { Lateral } 1 \text { / } \\
\text { 3rd }\end{array}$ \\
\hline Murlimanju BV et al. (2014) ${ }^{9}$ & $9.6 \%$ & $92.3 \%$ & $1.9 \%$ \\
\hline Rai R et al. (2014) ${ }^{12}$ & $10(15.4 \%)$ & $48(73.8 \%)$ & $7(10.8 \%)$ \\
\hline Tanna $N$ et al. $(2015)^{13}$ & $15(18.3 \%)$ & $59(72 \%)$ & $8(9.8 \%)$ \\
\hline Sowmiya G et al. $(2016)^{5}$ & $13(11.8 \%)$ & $100(90.9 \%)$ & $7(6.3 \%)$ \\
\hline Sahu S (2017) ${ }^{14}$ & $16(19.04 \%)$ & $60(71.42 \%)$ & $8(9.52 \%)$ \\
\hline $\begin{array}{l}\text { Joshi P et al. } \\
(2018)^{16}\end{array}$ & $1(2 \%)$ & $46(88.46 \%)$ & - \\
\hline Rekha et al. (2019) ${ }^{8}$ & $7(19 \%)$ & $10(33.3 \%)$ & $4(66.6 \%)$ \\
\hline Kumar D et al. $(2019)^{2}$ & --- & --- & --- \\
\hline Present study (2020) & $20(21.98 \%)$ & $66(72.52 \%)$ & $05(5.50 \%)$ \\
\hline
\end{tabular}

\begin{tabular}{|c|c|c|}
\hline Researchers & \multicolumn{2}{|c|}{$\begin{array}{l}\text { Direction of Nutrient Foramina } \\
\text { Towards Sternal End Towards Acromial End }\end{array}$} \\
\hline Murlimanju BV et al. (2014) ${ }^{9}$ & --- & $100 \%$ \\
\hline Rai R et al. $(2014)^{12}$ & --- & $100 \%$ \\
\hline Tanna N et al. $(2015)^{13}$ & --- & $100 \%$ \\
\hline Sowmiya G et al. $(2016)^{5}$ & $5(4.8 \%)$ & $98(95.1 \%)$ \\
\hline Sahu S $(2017)^{14}$ & -- & $100 \%$ \\
\hline Joshi P et al. ( 2018) ${ }^{16}$ & ---- & ---- \\
\hline Rekha et al. (2019) ${ }^{8}$ & $4.79 \%$ & $90.47 \%$ \\
\hline Kumar D et al. (2019)² & --- & $100 \%$ \\
\hline Present study (2020) & ----- & $100 \%$ \\
\hline $\begin{array}{r}\text { Table 7. Compar } \\
\text { Accord }\end{array}$ & $\begin{array}{l}\text { ison of Direction } \\
\text { ding to Different }\end{array}$ & Foramina \\
\hline
\end{tabular}

In our study, we observed that all the nutrient foramina were directed towards the acromial end. In the study conducted by the Murlimanju BV et al. ${ }^{9}$ Rai R et al. ${ }^{12}$ Tanna N et al. ${ }^{13}$ Sahu S, ${ }^{14}$ Joshi $P$ et al. ${ }^{16}$ and Kumar D et al. ${ }^{2}$ observed that all the nutrient foramina were directed towards the acromial end. Sowmiya G et al. ${ }^{5}$ and Rekha et al. ${ }^{8}$ found 5 (4.8 $\%$ ) and $4.79 \%$ of nutrient foramina directed towards the sternal end respectively. Lacroix P proposed that the certain abnormal nutrient foramina directions are due to the pull of muscle attachments on periosteum. ${ }^{9}$ Many authors have put the theories that explain the directions of the normal and abnormal nutrient foramina. In the literature, vascular theory of Hughes and the "periosteal slip" theory of Schwalbe are widely accepted. ${ }^{12}$ Longia GS et al. commented that all reported normal and abnormal nutrient canals are best explained by the vascular theory. ${ }^{16}$

In our study, mean length of the clavicle of right and left side was found $133.1 \pm 0.67 \mathrm{~mm}$ and $135.6 \pm 0.5 \mathrm{~mm}$ respectively. DNF of right and left clavicle was $63.2 \pm 1.21$ $\mathrm{mm}$ and $62.8 \pm 0.62 \mathrm{~mm}$ respectively. Foramina index (FI) was $47.48 \mathrm{~mm}$ and $46.31 \mathrm{~mm}$ of right and left side clavicle respectively. Sahu $\mathrm{S}$ et al. ${ }^{14}$ in their study found average length of clavicle as $126.38 \mathrm{~mm}$, DNF $65.8 \mathrm{~mm}$, and foramina index 52.06 respectively which is in concordance with our study.

\section{CONCLUSIONS}

The knowledge of number, location, and direction of nutrient foramina is useful for surgeons performing surgical procedures like internal fixation, coracoclavicular ligament repair, transplant techniques and bone grafting. The clinical knowledge of the nutrient foramina and its variations are important, as the microvascular bone transfer is becoming more popular where preservation of the circulation of affected bone is of vital importance for facilitating graft healing in the recipient.

Data sharing statement provided by the authors is available with the full text of this article at jemds.com.

Financial or other competing interests: None.

Disclosure forms provided by the authors are available with the full text of this article at jemds.com.

\section{REFERENCES}

[1] Chaurasia BD. Upper limb and thorax. In: BD Chaurasia's Human Anatomy. Vol. 1. $4^{\text {th }}$ edn. CBS Publishers \& Distributors 2005: p. 7-9.

[2] Kumar D, Raichandani L, Kataria SK, et al. Variation in number and position of nutrient foramen of clavicle-a morphological study in western Rajasthan. Indian Journal of Anatomy and Surgery of Head, Neck and Brain 2019;5(3):67-71.

[3] Devi VS. Upper limb thorax. In: Inderbir Singh's Textbook of Anatomy. Vol. 1. $7^{\text {th }}$ edn. Jaypee Brothers Medical Publishers 2019.

[4] Patel HG, Babariya D, Pensi CA. Nutrient foramina of dry human clavicle and their clinical significance. IJSR 2014;3(11):324-5.

[5] Sowmiya G, Sundarapandian S, Venugopal N. Neurovascular foramina of the human clavicle and their clinical significance. Research Journal of Pharmaceutical, Biological and Chemical Sciences 2016;7(6):2634-40.

[6] Sinha SK, Dhan MR, Hayat SM, et al. Morphometric study in the variations of number, position and direction of nutrient foramen in the clavicle. Int $\mathrm{J}$ Anat Res 2020;8(2.1):7454-7.

[7] Humphery GM. Observations on the growth of long bones and stumps. Med Chir Trans 1861;44:117-35.

[8] Rekha, Simriti. Morphometric study of nutrient foramen in dry human clavicle bones of Jammu Region. International Journal of Research and Analytical Reviews 2019;6(1):413-6.

[9] Murlimanju BV, Prashanth KU, Prabhu LV, et al. Morphological and topographical anatomy of nutrient foramina in human upper limb long bones and their surgical importance. Rom J Morphol Embryol 2011;52(3):859-62.

[10] Hughes H. The factors determining the direction of the canal for the nutrient artery in the long bones of mammals and birds. Acta Anat 1952;15(3):261-80.

[11] Fraizer JE. The anatomy of human skeleton. $2^{\text {nd }}$ edn. London, U.K.: J \& A Churchill Ltd., 1920:65-9.

[12] Rai R, Shrestha S, Kavitha B. Morphological and topographical anatomy of nutrient foramina in human clavicles and their clinical importance. Journal of Dental and Medical Science 2014;13(1):37-40.

[13] Tanna NA, Tanna VA. Anatomical variation in position, direction and number of nutrient foramina in clavicles. International Journal of Medical Science and Public Health 2015;4(3):357-9.

[14] Sahu SK, Meher D. Morphological and topographical anatomy of nutrientforamina in human clavicles of Eastern Odisha. International Journal of Applied Research 2017;3(4):521-3. 
[15] Knudsen FW, Andeson M, Karg C. The arterial supply of the clavicle. Surg Radiol Anat 1989;11(3):211-4.
[16] Joshi P, Mathur S. A comprehensive study of nutrient foramina in human upper limb long bones of Indian population in Rajasthan state. International Journal of Medical and Health Research 2018;4(8):6-11. 